10 Elmfeldt D, Wilhelmsen L, Tibblin G, Vedin JA, Wilhelmsson C-E, Bengtsson C. Registration of myocardial infarction in the city of Göteborg, Sweden. A community study. F Chronic Dis $1975 ; 28: 173-86$.

11 Blackburn H, Keys A, Simonson E, Rautahariu P, Punsar S. The electrocardiogram in population studies. A classification system. Circulation 1960;21: $1160-75$.

12 Astrand I, Areskog N-H, Carlsten A, et al. The "Minnesota code" for ECG classification. Adaptation to CR leads and modification of the code for ECG 3 rose GA. The diang and after exercise. Acta Med Scand [Suppl] 1967;481:1-26. field surveys. Bull WHO of ischaemic heart

14 Harmsen P, Tibblin G. A stroke register in Göteborg, Sweden. Acta Med Scand 1972;191:463-70.

15 Bradley JV. Distribution-free statistical tests. Englewood Cliffs, New Jersey: Prentice-Hall, 1968:68-86

16 Mantel N. Chi-square tests with one degree of freedom: extensions of the Mantel-Haenszel procedure. Fournal of the American Statistical Association 1963;58:690-700.
17 Kalbfleisch JD, Preptice RL. The statistical analysis of failure time data. New York: John Wiley and Sons, 1980.

18 Cox DR. Regression models and life tables. Fournal of the Royal Statistical Society (Series B) 1972;34:187-220.

19 Björntorp P, Sjöström L. Adipose tissue dysfunction and its consequences. In Cryer A, Van R, eds. New perspective in adipose tissue. London: Butterworths, 1984.

20 Larsson B, Björntorp P, Tibblin G. The health consequences of moderate obesity. Int $\mathcal{F}$ Obes $1981 ; 5: 97-116$.

21 Hubert HB, Feinleib M, McNamara PM, et al. Obesity as an independent risk factor for cardiovascular disease: a twenty-six year follow-up of Framingham Heart Study participants. Circulation 1983;67:968-77.

22 Waaler HTh. Height, weight and mortality. The Norwegian experience. Acta Med Scand [Suppl] 1984;679:1-56.

\title{
Long term follow up of untreated primary hyperparathyroidism
}

\author{
C R PATERSON，J BURNS， ELIZABETH MOWAT
}

\begin{abstract}
Fourteen patients with primary hyperparathyroidism and whose initial serum calcium concentrations were $2.75 \mathrm{mmol} / 1(11.0 \mathrm{mg} / 100 \mathrm{ml})$ or more were followed up for five to 23 years without operative treatment. One had osteitis fibrosa when seen and died with a fibrosarcoma 22 years later. The remaining 13 patients, who were followed up for a mean of 10 years, came to little obvious harm from not being operated on. Their serum calcium concentrations did not rise and there was no evidence of progressive renal impairment. In four patients who presented originally with renal calculi there were three further episodes of renal colic in 54 patient years of follow up.

Conservative management of primary hyperparathyroidism is not an unreasonable option, and patients who do not have symptoms need not necessarily be pressed to accept surgery.
\end{abstract}

\section{Introduction}

Primary hyperparathyroidism is increasingly recognised as a common disorder, particularly in older women. Many patients are symptom free; the classic symptoms of bone disorders, renal stones, or abdominal pain are uncommon. ${ }^{1}$ In the past it was usual to advise an exploration for all patients with primary hyperparathyroidism to prevent an "inevitable" decline in renal function. ${ }^{2-4}$ Now, however, it is clear that progressive renal impairment seldom occurs in mild primary hyperparathyroidism ${ }^{5}$ and, since exploration of the parathyroids has a small morbidity and mortality, ${ }^{6} 9$ more and more patients are being treated conservatively. ${ }^{10} \cdot 12$

Some workers think that most patients should be treated surgically. The reasons given are that they may not appreciate

\footnotetext{
Department of Biochemical Medicine, Ninewells Hospital and Medical School, Dundee

C R PATERSON, DM, FRCPATH, senior lecturer

J BURNS, MSC, FIMLS, medical laboratory scientific officer

Mercer Medical Centre, Mercer Barracks, BFPO 36

ELIZABETH MOWAT, MB, MRCGP, major, Royal Army Medical Corps
}

Correspondence to: Dr C R Paterson, Department of Biochemical Medicine, Ninewells Hospital, Dundee DD19SY. that they really have symptoms, that there is a risk of acute hypercalcaemia, that progressive osteopenia may occur, that medical follow up is expensive, and that if surgery is deferred the patient may be unfit for operation when indications for surgery do appear. ${ }^{1}{ }^{9} 13-16$

While these arguments continue in respect of patients with mild hypercalcaemia, most physicians advise an early parathyroid exploration for all, or almost all, patients with more severe hypercalcaemia. We describe a series of patients with hyperparathyroidism and serum calcium values of $2.75 \mathrm{mmol} / \mathrm{l}$

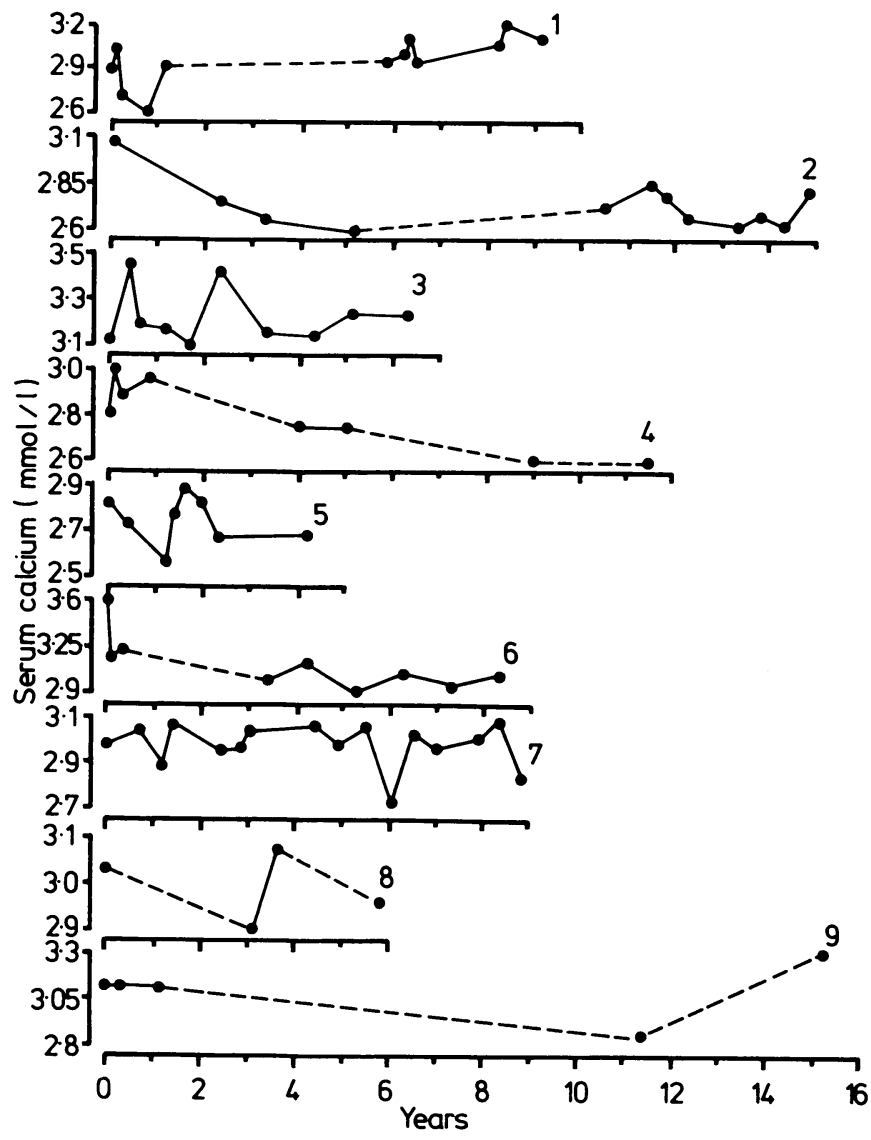

Serum calcium concentrations (adjusted for serum albumin value) in nine unoperated patients with primary hyperparathyroidism. For case 2 results of only first 15 years shown; table gives final figures after 23 years. 
Details of patients

\begin{tabular}{|c|c|c|c|c|c|c|c|c|c|c|c|}
\hline \multirow{2}{*}{$\begin{array}{l}\text { Case } \\
\text { No }\end{array}$} & \multirow{2}{*}{ Sex } & \multirow{2}{*}{$\begin{array}{c}\text { Age } \\
\text { initially }\end{array}$} & \multirow{2}{*}{$\begin{array}{c}\text { Years of } \\
\text { hypercalcaemia }\end{array}$} & \multirow{2}{*}{ Presentation } & \multirow{2}{*}{$\begin{array}{l}\text { Reason not } \\
\text { explored }\end{array}$} & \multirow{2}{*}{$\begin{array}{l}\text { Serum } \\
\text { parathyroid } \\
\text { hormone } \\
(\mathrm{U} / 1)\end{array}$} & \multicolumn{2}{|c|}{ Serum calcium $(\mathrm{mmol} / \mathrm{l})^{*}$} & \multicolumn{2}{|c|}{ Serum creatinine $(\mu \mathrm{mol} / \mathrm{l})$} & \multirow{2}{*}{ Outcome } \\
\hline & & & & & & & Initial & Final & Initial & Final & \\
\hline 1 & $\mathbf{F}$ & 54 & 9 & Sarcoidosis & $\begin{array}{l}\text { Hypercalcaemia } \\
\text { attributed to } \\
\text { sarcoid }\end{array}$ & $0 \cdot 38$ & $2 \cdot 89$ & 3.09 & 88 & 77 & $\begin{array}{l}\text { Asymptomatic while } \\
\text { sarcoid controlled. } \\
\text { Parathyroidectomy }\end{array}$ \\
\hline 2 & $\mathrm{~F}$ & 49 & 23 & Renal colic & $\begin{array}{c}\text { Unsuccessful } \\
\text { exploration }\end{array}$ & 0.60 & 3.07 & 2.73 & 70 & 57 & $\begin{array}{l}\text { One further episode } \\
\text { of renal colic. } \\
\text { Otherwise } \\
\text { symptomless }\end{array}$ \\
\hline 3 & M & 70 & 6 & $\begin{array}{l}\text { Screening when } \\
\text { admitted for } \\
\text { cataract }\end{array}$ & Patient declined & $0 \cdot 40$ & $3 \cdot 13$ & $3 \cdot 23$ & 146 & 109 & Symptomless \\
\hline 4 & $\mathrm{~F}$ & 68 & 11 & Arthropathy & Patient's age & 0.48 & $2 \cdot 80$ & 2.58 & 75 & 81 & $\begin{array}{l}\text { Arthropathy. } \\
\text { Normocalcaemic for } \\
\text { final two years: } \\
\text { ?infarction of } \\
\text { adenoma }\end{array}$ \\
\hline 5 & $\mathrm{~F}$ & 60 & 5 & $\begin{array}{l}\text { Chronic } \\
\text { obstructive } \\
\text { airways } \\
\text { disease }\end{array}$ & $\begin{array}{l}\text { Severity of } \\
\text { respiratory } \\
\text { disability }\end{array}$ & - & $2 \cdot 82$ & $2 \cdot 71$ & 80 & 117 & $\begin{array}{l}\text { Died: respiratory } \\
\text { failure }\end{array}$ \\
\hline $\begin{array}{l}6 \\
7\end{array}$ & $\underset{F}{F}$ & $\begin{array}{l}71 \\
64\end{array}$ & $\begin{array}{l}8 \\
9\end{array}$ & $\begin{array}{l}\text { Low back pain } \\
\text { Carcinoma of } \\
\text { colon }\end{array}$ & $\begin{array}{l}\text { Patient declined } \\
\text { Rheumatic } \\
\text { heart disease }\end{array}$ & $\begin{array}{l}1 \cdot 10 \\
0.60\end{array}$ & $\begin{array}{l}3.59 \\
2.96\end{array}$ & $\begin{array}{l}2.98 \\
2 \cdot 86\end{array}$ & $\begin{array}{l}106 \\
107\end{array}$ & $\begin{array}{l}107 \\
107\end{array}$ & $\begin{array}{l}\text { Symptomless } \\
\text { Parathyroidectomy }\end{array}$ \\
\hline 8 & $\mathrm{~F}$ & 76 & 6 & $\begin{array}{l}\text { (resected) } \\
\text { Arthropathy }\end{array}$ & Patient's age & 0.41 & 3.03 & 2.96 & 69 & 68 & Arthropathy, other- \\
\hline 9 & $\mathrm{~F}$ & 61 & 15 & Nail dystrophy & $\begin{array}{l}\text { Unsuccessful } \\
\text { exploration; } \\
\text { repeat declined }\end{array}$ & - & $3 \cdot 12$ & $3 \cdot 30$ & - & 94 & $\begin{array}{l}\text { Symptomless for } \\
14 \text { years. Died: } \\
\text { cardiac infarction }\end{array}$ \\
\hline 10 & $\mathrm{~F}$ & 35 & 8 & Renal calculi & Misadventure $\ddagger$ & 0.33 & $3 \cdot 13^{*}$ & $3 \cdot 16$ & - & 90 & $\begin{array}{l}\text { Symptomless for } 6 \\
\text { years. Died: } \\
\text { carcinoma of } \\
\text { pharynx }\end{array}$ \\
\hline 11 & $M$ & 59 & 7 & $\begin{array}{l}\text { Ischaemic } \\
\text { heart disease, } \\
\text { duodenal } \\
\text { ulcer; calculi } \\
20 \text { years before }\end{array}$ & $\begin{array}{l}\text { Congestive } \\
\text { cardiac failure }\end{array}$ & - & $2 \cdot 79$ & $3 \cdot 02$ & - & 141 & $\begin{array}{l}\text { Died: cardiac } \\
\text { infarction }\end{array}$ \\
\hline 12 & $\mathrm{~F}$ & 49 & 8 & Renal calculi & Misadventure $\ddagger$ & - & $2 \cdot 92$ & $2 \cdot 89$ & - & 74 & $\begin{array}{l}\text { Symptomless. } \\
\text { Parathyroidectomy }\end{array}$ \\
\hline 13 & $\mathrm{~F}$ & 53 & 15 & Renal colic & Patient declined & $0 \cdot 25$ & $2 \cdot 75$ & $2 \cdot 74$ & - & 89 & $\begin{array}{l}\text { Symptomless apart } \\
\text { from two further } \\
\text { episodes of renal } \\
\text { colic. }\end{array}$ \\
\hline 14 & $\mathrm{~F}$ & 49 & $22 \dagger$ & Bone pain & Misadventure + & - & - & $2 \cdot 90$ & - & 135 & $\begin{array}{l}\text { Parathyroidectomy } \\
\text { Died: sarcoma. Large } \\
\text { parathyroid } \\
\text { adenoma at necropsy }\end{array}$ \\
\hline
\end{tabular}

*All serum calcium values adjusted for serum albumin except where marked with asterisk.

+Years of recognisable hyperparathyroidism. Only five years of known hypercalcaemia.

with typical symptoms of hyperparathyroidism but for whom no appropriate action taken at the time.

Conversion. SI to traditional units -Calcium: $1 \mathrm{mmol} / \mathrm{l} \approx 4 \mathrm{mg} / 100 \mathrm{ml}$ Creatinine: $1 \mu \mathrm{mol} / 1 \approx 0.01 \mathrm{mg} / 100 \mathrm{ml}$.

$(11.0 \mathrm{mg} / 100 \mathrm{ml})$ or more who for various reasons were left unoperated for five to 23 years and examine the clinical and biochemical consequences of such long periods of untreated severe hyperparathyroidism.

\section{Patients}

Among 200 local patients with primary hyperparathyroidism, 13 (see table) had had initial serum calcium values of $2.75 \mathrm{mmol} / \mathrm{l}$ or more and had been followed up for at least five years (range 5-23 years; mean 10). All the patients in whom serum parathyroid hormone concentration was measured had detectable or raised values. None had a family history of hypercalcaemia, and none had the hypocalciuria typical of familial benign hypercalcaemia. Most of the patients were identified by chance after presenting with an unrelated illness, but four had renal colic.

One patient (case 14) presented with bone pain and a cystic lesion of the ilium. At that time the sole concern of the clinicians was the exclusion of malignancy, and no histological evidence of malignancy was found; when the blocks were reviewed afterwards osteitis fibrosa was obvious. Hypercalcaemia was not identified until 17 years later, and even then exploration of the parathyroids was not advised. She died aged 71 with fibrosarcoma of the ilium; a large parathyroid adenoma was found at necropsy.

\section{Results}

In these patients serum calcium concentrations were remarkably stable over the long periods of follow up. The figure shows the values for serum calcium (adjusted for serum albumin concentration) in the nine patients for whom there were reasonably full data. Calcium concentrations remained remarkably constant, and no cases of acute hypercalcaemia were seen. The serum creatinine value remained normal in every case despite the long period of hypercalcaemia (table). Of the patients who died, all but two died of the progression of disorders known to be present when the hypercalcaemia was first found. Among the four patients presenting with renal colic there were only three further episodes of colic in 54 patient years of follow up.

Skeletal symptoms were uncommon; two patients had longstanding arthropathies, which were troublesome throughout the periods of follow up. There was one fractured neck of femur (case 9, age 75). The only patient with vertebral collapse (case 14) was known to have had osteitis fibrosa.

\section{Discussion}

In view of the initial serum calcium concentrations in these patients $(2.75 \mathrm{mmol} / 1(11.0 \mathrm{mg} / 100 \mathrm{ml})$ or more $)$ we have no doubt that ordinarily they would have been advised to have a parathyroid exploration. Some were not so advised because of other medical problems, others refused surgery, and the remainder were left untreated because of clinical misadventures. Despite their appreciable hypercalcaemia there was no change in serum creatinine concentrations over the long periods of follow up. These results are similar to those obtained for shorter periods by other workers. ${ }^{11} 17$

The risk of progressive osteopenia is often regarded as a reason to recommend parathyroid exploration. In our series, with the exception of the patient with known osteitis fibrosa (case 14), skeletal symptoms were uncommon despite the fact that there were seven women aged more than 70 at the end of the study. The fatal sarcoma in case 14 may have been caused by longstanding osteitis fibrosa but may also have resulted from radiotherapy to the ilium 21 years before. ${ }^{19} 1$ Whatever the 
cause the patient was clearly the victim of several clinical and diagnostic misadventures and should have had a parathyroid exploration. With this exception our patients with severe hyperparathyroidism came to little obvious harm when left untreated.

Primary hyperparathyroidism is increasingly recognised as a common disorder. Some 60000 new cases occur each year in the United States, ${ }^{20}$ and in Britain the widespread use of routine serum calcium assays might yield 13000 new cases yearly. ${ }^{21}$ Were parathyroid exploration regarded as mandatory the cost would be large ${ }^{22}$ and some morbidity and mortality would be inevitable.

Patients with symptoms such as renal calculi, peptic ulceration, pancreatitis, or fractures should certainly be advised to have a parathyroidectomy. It is more difficult to assess the relevance of non-specific symptoms such as depression and lassitude as indications for surgery. Some patients undoubtedly benefit ${ }^{115}$; in others the operation may serve as a powerful placebo. ${ }^{23}$ Hypertension is more common in hyperparathyroid subjects than in age matched controls ${ }^{22}$ but is seldom relieved by a successful parathyroidectomy and cannot by itself be regarded as an indication for surgery. ${ }^{11}$

Indications for parathyroid surgery in apparently symptomless patients remain controversial. It is clear from our study that, untreated, such patients do not necessarily have progressive renal damage and seldom develop skeletal problems or acute hypercalcaemia. Conservative management is not an unreasonable option and patients without symptoms need not be bullied into having surgery.

We are indebted to Professor G H Bell for comments on the text and to $\mathrm{Mr} \mathrm{N} S$ Brown for the parathyroid hormone assays.

\section{References}

1 Heath DA, Wright AD, Barnes AD, Oates GD, Dorricott NJ. Surgical treatmen of primary hyperparathyroidism in the elderly. $\mathrm{Br} M e d \mathcal{F}_{1980 ; 280: 1406-8}$. ,

1968.
Coe FL, Favus MJ. Does mild, asymptomatic hyperparathyroidism require

tevenson JC, Lynn J. Mild asymptomatic hyperparathyroidism. $\mathrm{Br}$ Med $\mathcal{f}$ 1980;281:520-1.

Scholz DA, Purnell MD. Asymptomatic primary hyperparathyroidism. Mayo Clin Proc $1981 ; 56: 473-8$.

Gough MH, Smith R, Bishop MC. Parathyroidectomy for symptomless hyperparathyroidism: a surgical dilemma. Lancet 1971 ; i:1178.

Myers RT. Follow up study of surgically-treated primary hyperparathyroidism Ann Surg 1974;179:729-33.

8 Scott HW, Richie RE, Crane JM, et al. Surgical experience with hyperparathyroidism. Am Surg 1981;47:54-62.

ifschitz BM, Barzel UR. Parathyroid surgery in the aged. $\mathcal{F}$ Gerontol $1981 ; 36$ $573-5$

ilezikian JP. The medical management of primary hyperparathyroidism.

11 Van't Hoff W, Ballardie FW, Bicknell EJ. Primary hyperparathyroidism: the case for medical management. $\mathrm{Br} M e d \mathcal{F} 1983 ; 287: 1605-8$.

$12 \mathrm{Gaz}$ RD, Wang C. Management of asymptomatic hyperparathyroidism. Am f Surg 1984;147:498-502.

13 Kaplan RA, Snyder WH, Stewart A, Pak CYC. Metabolic effects of parathy roidectomy in asymptomatic primary hyperparathyroidism. F Clin Endocrinol Metab 1976;42:415-26.

14 Graham JJ, Harding PE, Hoare LL, Thomas DW, Wise PH. Asymptomatic hyperparathyroidism: an assessment of operative intervention. Br $\mathcal{F}$ Surg

15 Fiatarone MA, Steel K, Egdahl RH. Hyperparathyroidism in the elderly.

500 CF, Edis AJ. Surgery for primary hyperparathyroidism: experience with and evaluation of the role of surgery in the asymptomatic patient. Br $\mathcal{F}$ Surg 1982;69:244-7.

Med $\mathcal{F}$ A ust $1981 ; \mathrm{i}: 519-21$.

18 Cahan WG, Woodard HQ, Higinbotham NL, Stewart FW, Coley BL. Sarcoma arising in irradiated bone. Cancer 1948;1:3-29.

he SK, Qasim MM, Talerman A. A soft tissue sarcoma occurring four years after radiotherapy. Br f Radiol 1976;49:893-4.

20 Hodgson SF, Heath $\mathrm{H}$. Asymptomatic primary hyperparathyroidism: treat or follow ? Mayo Clin Proc $1981 ; 56: 521-2$.

21 Mundy GR, Cove DH, Fisken R. Primary hyperparathyroidism: changes in the

MA. Primary hyperparathyroidism. $N$ Engl $f$

年

thyroidism. Aust NZ F Med 1979;9:17-23.

(Accepted 29 Augnst 1984)

\title{
Loperamide in acute diarrhoea in childhood: results of a double blind, placebo controlled multicentre clinical trial
}

\author{
DIARRHOEAL DISEASES STUDY GROUP (UK)
}

\begin{abstract}
A total of 315 young children with acute diarrhoea were included in a double blind, hospital based multicentre trial of loperamide at two dose levels $(0.8 \mathrm{mg}$ and $0.4 \mathrm{mg} /$ $\mathrm{kg} / 24 \mathrm{~h}$ ), given with standard oral rehydration therapy versus placebo plus oral rehydration therapy. The overall recovery rate was slowest in the placebo group and fastest in the group given loperamide $0.8 \mathrm{mg}$. Com-
\end{abstract}

Members of the study group were: Dr N A P Evans (Royal Alexandra Hospital for Sick Children, Brighton); Professor R G Hendrickse (study coordinator; Alder Hey Children's Hospital and Department of Tropical Paediatrics, Liverpool School of Tropical Medicine); Ms S B J Macfarlane (Statistics Unit, Department of Tropical Paediatrics, Liverpool School of Tropical Medicine); Dr H E Meiring (Queen Elizabeth Hospital for Children, London); Dr P J Milla (Institute of Child Health, University of London); Mr J B Moody (Statistics Unit, Department of Tropical Paediatrics, Liverpool School of Tropical Medicine); Dr B K Sandhu (Institute of Child Health, University of London); Dr M L Smith (Leeds Road Hospital, Bradford); Dr C J Taylor (Alder Hey Children's Hospital and Department of Tropical Paediatrics, Liverpool School of Tropical Medicine); Dr J A Walker-Smith (Queen Elizabeth Hospital for Children, London).

Correspondence to: Professor R G Hendrickse, Department of Tropical Paediatrics, Liverpool School of Tropical Medicine, Liverpool L3 5QA. parisons between weights on admission and weights by day 3 showed that a larger proportion of children in the loperamide groups gained weight than in the placebo group. No serious side effects of loperamide were observed, but the drug was withdrawn in one infant because of mild abdominal distention.

The results indicate that loperamide, in the doses employed, is safe and may in selected cases be a useful adjunct to oral rehydration in the management of acute diarrhoea in well nourished children.

\section{Introduction}

Glucose-electrolyte solutions are highly effective in treating dehydration in acute diarrhoea by stimulating glucose coupled sodium transport in the small intestine. ${ }^{12}$ The use of adjunct therapy in oral rehydration remains controversial, but agents that effectively inhibit the net secretion of fluid and electrolytes by the intestine without serious side effects may have a place.

Naturally occurring opioids have been used as antidiarrhoeal agents since antiquity but their central effects make them undesirable. Loperamide, a recently developed opioid analogue, differs from other, similar drugs in that it binds predominantly to intestinal tissue and when given by mouth has virtually no 